\title{
PENGELOLAAN DAN PEMBERDAYAAN \\ GURU NON PNS PADA MADRASAH NEGERI DI KOTA KENDARI
}

\section{Israpil*}

Balai Peneitian dan Pengembangan Agama Makassar Jl. AP.Pettarani No. 72 Makassar Email: israpilpenda@gmail.com

\section{INFO ARTIKEL}

\section{Kata Kunci:}

Pengelolaan,

Pemberdayaan,

Guru Non PNS,

Madrasah

\section{Keywords: \\ Management, \\ Empowerment, Non \\ PNS Teachers, \\ Madrasah}

\section{ABSTRAK}

Penelitian ini bertujuan untuk mengetahui bagaimana bentuk pengelolaan dan pemberdayaan guru non PNS pada madrasah negeri di Kota Kendari. Penelitian ini adalah penelitian survei pada taraf deskriptif kualitatitf, dengan menyasar guru non PNS pada tiga madrasah negeri, yaitu Madrasah Ibtidaiyah Negeri (MIN) Kota Kendari, Madrasah Tsanawiyah Negeril (MTsN 1) Kota Kendari, dan Madrasah Aliyah Negeri 1 (MAN 1) Kota Kendari. Pengumpulan data dilakukan dengan wawancara mendalam, pengedaran angket dan serta penelusuran dokumen administrasi madrasah. Hasil penelitian menunjukkan bahwa pengelolaan guru non PNS pada madrasah prosesnya dimulai dari rekruitmen sampai kepada penugasannya dilakukan secara mandiri dengan kriteria yang telah ditetapkan oleh kepala madrasah. Guru non PNS di madrasah dari aspek pemberdayaan, pada prinsipnya mendapat perlakuan yang sama dengan guru PNS, khususnya dalam hal pengembangan kompetensi, Pada setiap pelaksanaan workshop, diklat, kegiatan MGMP, KKG, mereka tetap dilibatkan meskipun dengan kuantitas yang masih minim. Jaminan ekonomi guru non PNS berupa gaji bulanan dan pendapatan insentif lainnya hanya bersumber dari dana Biaya Operasional Sekolah (BOS) dan dana komite sekolah. Jaminan ekonomi tersebut belum bisa mencukupi kebutuhan hidup mereka sehari-hari.

\section{ABSTRACT}

This study aims to determine how the form of management and empowerment of non-PNS teachers in public madrasas in Kendari City. This study is a survey research at a descriptive qualitative level, targeting non civil servant teachers in three public madrasas, namely Madrasah Ibtidaiyah Negeri (MIN) Kendari City, Madrasah Tsanawiyah Negeril (MTsN 1) Kendari City, and Madrasah Aliyah Negeri 1 (MAN 1) Kota Kota Kendari. Data collection was carried out by in-depth interviews, distribution of questionnaires and searching of madrasah administrative documents. The results showed that the management of non-PNS teachers in madrasas began from the recruitment process to the assignment done independently with the criteria set by the madrasa headmaster. Non-PNS teachers in madrasas from the aspect of empowerment, in principle, receive the same treatment as PNS teachers, especially in terms of competency development. In every workshop, training, $M G M P, K K G$ activities, they are still involved even with a minimal quantity. Non-PNS teacher economic guarantees in the form of monthly salaries and other incentive income are only sourced from the School Operational Cost (BOS) and school committee funds. The economic guarantee cannot fulfill their daily needs.

\section{PENDAHULUAN}

Di satu sisi guru yang tersedia tidak sebanding dengan peningkatan siswa dari tahun ke tahun, sehinga mau tidak mau satuan pendidikan madrasah perlu mengangkat guru pada sisi yang lain. Dalam upaya untuk memenuhi kebutuhan guru madrasah. Pemerintah Republik
Indonesia telah melakukan kebijakan pengangkatan guru PNS melalui seleksi penerimaan guru PNS.

Terdapat sejumlah 84.236 orang guru yang berstatus PNS yang tersebar di sejumlah 38.206 satuan pendidikan. (Education Manajemen Information System 
(EMIS), 2017). Dari paparan tersebut, maka ada sejumlah 1-3 orang guru PNS pada setiap institusi pendidikan. Sementara realitasnya di lapangan distribusi guru tidak demikian, sebab dominan guru PNS terkonsentrasi pada madrasah negeri. Ada ketimpangan distribusi guru yang sangat besar antra madrasah negeri dan swasta. distribusi guru PNS lebih condong ke negeri. Jika asumsi tersebut dipergunakan maka terhitung bahwa terdapat sejumlah 26-27 orang PNS di setiap madrasah negeri. Kondisi prediksi terakhir ini juga tidak realistik, sebab jumlah guru PNS dominan bertugas di madrasah negeri ibukota provinsi dari pada di daerah-daerah kabupaten. (Badruzzaman, 2019:1).

Kebijakan pengangkatan guru PNS ini tidaklah berdampak maksimal untuk mengatasi kekurangan guru di madrasah, karena saat ini negara hanya mampu mengangkat sebagian kecil guru PNS. Kondisi ini disebabkan oleh kemampuan negara untuk menanggung gaji dan tunjangan guru. Di samping itu, pendirian MAN IC di sejumlah provinsi berlangsung beberapa tahun terakhir. Kehadiran lembaga pendidikan ini menyebabkan jumlah MAN bertambah. Pendirian institusi ini tampaknya tidak disertai dengan rekrutmen guru dengan status PNS. Akibatnya, pengangkatan guru honorer untuk memenuhi kebutuhan itu tidak dapat dielakkan. Bagi pihak madrasah, proses pembelajaran harus segera berjalan karena siswa sudah ada. (Hamdar Arraiyyah. https://blamakassar.co.id/2019/10/22/guruhonorer-di-madrasah-negeri-peluangtantangan-dan-respons/Diakses, tanggal 23/10/2019)

Telah diprediksi terdapat sejumlah 34 orang guru non PNS pada setiap madrasah. Jumlah tersebut tidaklah dapat memenuhi pelaksanaan pembelajaran secara maksimal, karena dapat dipastikan sebagian besar guru non PNS mengajarkan dua atau lebih mata pelajaran, meskipun kualifikasinya mismatch. Selain itu dominan guru non PNS bertugas di madrasah swasta. Jika asumsinya demikian maka dapat diprediksi bahwa di setiap madrasah swasta terdapat sejumlah 4-5 orang guru non PNS. Namun kondisinya tidak demikian sebab dominan guru honorer (non PNS) bertugas di madrasah swasta di bawah naungan pesantren dan/atau madrasah swasta unggulan. (Badruzzaman, 2019:1).

Permasalahan rekrutmen guru non PNS tampaknya tidak maksimal memecahkan permasalahan pendidikan di madrasah. Masalah mengenai guru non PNS tidak habis habisnya bermunculan. Antara lain tingkat kesejahteraan guru non PNS sangat rendah. Guru non PNS hanya digaji berdasarkan jam mengajarnya meskipun mereka berada di madrasah sepanjang waktu sekolah.

Kesejahteraan Guru non PNS berupa gaji/honor hanya diperoleh dari pemanfaatan dana Biaya Operasional Sekolah (BOS) dan atau Biaya Operasional Madrasah (BOM) tidak mencukupi biaya hidup sehari-hari. Pendapatan lain yang diharapkan dari kebijakan pemberian tunjangan guru non PNS dari pemerintah setempat belum memadai. Beberapa guru non PNS sudah lulus ujian sertifikasi guru, meskipun berimplikasi pada perolehan tunjangan sertifikasi guru, namun sejumlah pencairan dana tersebut banyak menemui kendala, hanya mengutamakan guru PNS.

Dalam hal program peningkatan kompetensi guru sangat jarang menyasar guru non PNS. Hal serupa dengan pemberdayaan mereka pada kegiatankegiatan peningkatan kualitas pembelajaran di madrasah.

Berdasarkan latar belakang di atas, maka penelitian ini urgen dilakukan untuk mengamati secara mendalam tentang pengelolaan dan pemberdayaan guru non PNS pada madrasah di Kota Kendari.

\section{TINJAUAN TEORITIS \\ Pengelolaan}

Menurut Kamus Besar Bahasa Indonesia, bahwa pengertian pengelolaan adalah proses melakukan kegiatan tertentu 
dengan menggerakkan tenaga orang lain. (https://typoonline.com.>kbbi.13/09/2018).

Menurut Suharsimi Arikunto, pengelolaan dan manajemen mempunyai pengertian yang sama, yaitu diartikan sebagai pengaturan, atau pengurusan. Arikunto, 1993:31). Manajemen secara populer dipahami sebagai pengaturan, pengelolaan, dan administrasi. Namun Griffin menyatakan bahwa manajemen sebagai berikut: "Management is the process of planning and decision making, organizing, leading and controlling and organization human, financial, physical and information recources to archieve organizational goals in an efficient and effective manner". Artinya: manajemen adalah suatu proses perencanaan dan pengambilan keputusan, pengorganisasian, memimpin dan pengendalian organisasi manusia, keuangan, fisik dan informasi sumber daya untuk mencapai tujuan organisasi secara efisiensi dan efektif. (Griffin, 1990:6).

Sementara pendapat Stoner, bahwa manajemen adalah proses mulai dari perencanaan, kemudian pengarahan, sampai kepada pengawasan kepada usahausaha yang dijalankan oleh para anggota organisasi atau user lainnya untuk tujuan tertentu menjadi tujuan akhirnya. Aspek yang lebih ditonjolkan Stoner adalah pada manajemen, proses dan sistem. Menurutnya jika proses perencanaan, pengorganisasian, pengarahan, penganggaran, dan sistem pengawasan tidak baik, maka proses manajemen secara keseluruhan tidak lancar sehingga proses pencapaian tujuan akan terganggu atau mengalami kegagalan. (Qalyubum, 2007:271).

Jadi manajemen dapat diartikan sebagai proses merencanakan, mengorganisir, memimpin, dan mengendalikan. Ia merupakan serangkaian aktivitas untuk mengoordinasi kegiatan. Ia mencakup perencanaan, pengorganisasian, pengarahan, pengendalian, penempatan, serta pengambilan keputusan untuk menghasilkan suatu produk dan jasa yang efektif dan efisien. Fungsi manajemen, meliputi: planning (perencanaan), organizing (pengorganisasian), actuating (pengarahan), dan controlling (pengawasan) (Fattah, 2004:1)

\section{a. Planning (Perencanaan)}

Menurut Sutanto, perencanaan adalah sebagai perhitungan dan penentuan apa yang dijalankan untuk mencapai tujuan tertentu, oleh siapa pelaku itu atau pelaksana dan bagaimana tata cara mencapai itu. (Sutanto NS, 2004:109). Cropper berpendapat: Planning is the basis from which all other function are spawned. Without a congruent plan, organizations usually lack a central focus. Artinya: Bahwa perencanaan adalah dasar yang akan dikembangkan menjadi seluruh fungsi berikutnya. Tanpa rencana yang tepat dan padu sebuah organisasi akan kehilangan fokus sentral berpijak bukan sekadar daftar kegiatan yang harus 5 dilakukan. (Fattah, 2004:1)

Suharsimin Arikunto, cakupan perencanaan, yaitu: apa yang dilakukan, siapa yang melakkukan, di mana akan dilakukan, apa saja yang diperlukan agar tercapainya tujuan dapat dilakukan, bagaimana melakukannya, apa saja yang dilakukan agar tercapainya tujuan dapat maximum? (Arikunto, 1993:38).

\section{b. Organizing (Pengorganisasian)}

Rue dan Byars berpendapat: Organizing is grouping activities, assigning activities an providing the authority necessary to carry out the activities. (Byars, 1980:6). Artinya: Pengorganisasian merupakan upaya mengelompokkan kegiatan-kegiatan menugaskan kegiatankegiatan, menyediakan keperluan, mengatur wewenang untuk melaksanakan kegiatan tersebut.

Pengorganisasian pada intinya adalah pembagian tugas atau pekerjaan, di antara para anggota organisasi untuk mencapai tujuan tertentu. Untuk mencapai itu, maka perlu dipilihlah orang-orang yang berkompenten. Aspek-aspek yang perlu menjadi perhatian untuk memilih orang 
yang berkompeten ada proses penarikan, penempatan, pemberian latihan dan pengembangan anggota-anggota organisasi.

\section{c. Actuating (Pengarahan)}

Pengarahan dimaksudkan adalah kekuatan pribadi atau power seseorang mampu memengaruhi demi untuk kepentingan jangka panjang perusahaan. Termasuk di dalamnya bagaimana memberitahukan orang lain apa yang diinginkan bisa dilakukan sesuai dengan tujuan agar tugas-tugas dapat diselesaikan dengan baik. Bahkan untuk mencapai tujuan tersebut, ada paksaan dan ancaman.

Pengarahan dominan dipraktekan oleh para manajer atau pimpinan perusahaan. Tidak sekadar memberikan arahan atau perintah tapi juga menciptakan iklim yang bisa membantu para bawahan melakukan pekerjaan dengan baik, efektif, efesien, serta menciptakan lingkungan kerja yang lebih sehat dan dinamis.

\section{d. Controlling (Pengawasan)}

Controlling (pengawasan) adalah mengukur dan membandingkan pekerjaan sedang atau sudah dilaksanakan dengan kriteria, norma-norma standar atau rencanarencana yang sudah ditetapkan sebelumnya. (Sutarno NS, 2004:128).

Controlling dapat dimaknai monitoring dan evaluasi, agar ada perbaikan untuk kegiatan berikutnya, sehingga apa yang direncanakan itu tercapai dengan maksimal. Biasanya pengawasan atau kontroling merupakan bagian terakhir dari fungsi manajemen.

\section{Pemberdayaan}

Pemberdayaan dapat dimaknai sebagai upaya untuk membangun potensi yang dapat dikembangkan untuk membangkitkan sprit yang dimiliki oleh setiap manusia dan masyarakat. (Kartasasmita, 1996:29).

Menurut Kartasasmita, pemberdayaan masyarakat dapat diwujudkan dengan: Pertama, menciptakan suasana atau iklim yang memungkinkan potensi masyarakat berkembang (enabling). kedua, memperkuat potensi atau daya yang dimiliki oleh masyarakat (empowering). ketiga, memberdayakan mengandung pula arti melindungi. (Kartasasmita, 1996:24).

\section{Enabling}

Enabling atau menciptakan suasana atau iklim menjadi pemicu berkembangnya potensi guru non PNS berkembang. Perbedaan dalam setiap pekerjaan yang telah dirancang di suatu orgasasi telah memiliki strategi dalam mengelola sumber daya manusia. Iklim organisasi yang terbuka memacu karyawan lebih leluasa dalam bertindak. Ketidakpuasan bisa diminimalisir dengan cara yang positif dan bijaksana.

Selain itu, dalam perspektif mikro atau tinjauan secara sempit dan khusus, faktor dominan yang berpengaruh dan berkontribusi besar terhadap mutu pendidikan ialah guru yang profesional dan guru yang sejahtera. Oleh karena itu, guru sebagai suatu profesi harus profesional dalam melaksanakan berbagai tugas pendidikan dan pengajaran, pembimbingan dan pelatihan yang diamanahkan kepadanya. (Manaf, 2016:116).

Guru atau tenaga pendidikan sebagai tokoh sentral dalam mengelolah proses pembelajaran di sekolah. Dengan adanya pemberdayaan guru dapat memberikan dampak positif terhadap peningkatan professionalisme dalam kegiatan pembelajaran di sekolah.

Pemberdayaan guru di sekolah, menjadi kunci utama dalam upaya peningkatan profesionalisme guru dan mutu pendidikan di sekolah, serta di dukung oleh faktor lain yang berkaitan dengan sumber daya sekolah. (Manaf, 2016:116).

\section{Empowering}

Upaya untuk memperkuat potensi atau daya yang dimiliki oleh guru non PNS adalah dengan empowering. Menurut Elizabeth empowering merupakan upaya yang dilakukan untuk menunjukkan 
penguatan terhadap segala yang berada dalam keadaan tidak berdaya sehingga empowering diharapkan mampu menolong dirinya sendiri dalam mengembangkan semangat kepercayaan yang telah ada. (Kartasasmita, 1996:24). Dalam konteks guru non PNS peningkatan potensi tentunya berkaitan dengan kompetensi sebagai guru. Berdasarkan Undang-Undang Republik Indonesia Nomor 14 Tahun 2005 Tentang Guru Dan Dosen, pada pasal 14 dinyatakan bahwa "Dalam melaksanakan tugas profesionalitas, guru berhak: $d$. Memperoleh kesempatan untuk meningkatkan kompetensi. Ada empat kompetensi, yaitu kompetensi pedagogik, profesional, sosial dan kepribadian (Peraturan Menteri Pendidikan Nasional Republik Indonesia Nomor 16 Tahun 2007 Tentang Standar Kualifikasi Akademik dan Kompetensi Guru). Sementara guru pendidikan agama diberikan tambahan kompetensi yaitu kompetensi kepemimpinan.

Kategori-kategori keempat kompetensi guru yang wajib dimiliki oleh guru menurut Permendiknas Nomor 16 Tahun 2007, adalah sebagai berikut: Pertama, kompetensi pedagogik meliputi: a) Menguasai karakteristik peserta didik dari aspek fisik, moral, sosial, kultural, emosional, dan intelektual; b) Menguasai teori belajar dan prinsip-prinsip pembelajaran yang mendidik; c) Mengembangkan kurikulum yang terkait dengan bidang pengembangan yang diampu; d) Menyelenggarakan kegiatan pengembangan yang mendidik; e) Memanfaatkan teknologi informasi dan komunikasi untuk kepentingan penyelenggaraan kegiatan pengembangan yang mendidik; f) Memfasilitasi pengembangan potensi peserta didik untuk mengaktualisasikan berbagai potensi yang dimiliki; g) Berkomunikasi secara efektif, empati, dan santun dengan peserta didik; h) Menyelenggarakan penilaian dan evaluasi proses dan hasil belajar; i) Memanfaatkan hasil penilaian dan evaluasi untuk kepentingan pembelajaran; dan j)
Melakukan tindakan reflektif untuk peningkatan kualitas pembelajaran.

Kedua, kompetensi kepribadian meliputi: a) Bertindak sesuai dengan norma agama, hukum, sosial, dan kebudayaan nasional Indonesia; b) Menampilkan diri sebagai pribadi yang jujur, berakhlak mulia, dan teladan bagi peserta didik dan masyarakat; c) Menampilkan diri sebagai pribadi yang mantap, stabil, dewasa, arif, dan berwibawa; d) menunjukkan etos kerja, tanggungjawab yang tinggi, rasa bangga menjadi guru, dan rasa percaya diri; e) Menjunjung tinggi kode etik profesi guru; f) Bersikap inklusif, bertindak objektif, serta tidak diskriminatif karena pertimbangan jenis kelamin, agama, ras, kondisi fisik, latarbelakang keluarga, dan status sosial ekonomi; g) Berkomunikasi secara efektif, empati, dan santun dengan sesama pendidik, tenaga kependidikan, orang tua, dan masyarakat; h) Beradaptasi di tempat bertugas di seluruh wilayah Republik Indonesia yang memiliki keragaman sosial budaya; dan i) Berkomunikasi dengan komunitas profesi sendiri dan profesi lain secara lisan dan tulisan atau bentuk lain.

Ketiga, kompetensi sosial meliputi: a) Bersikap inklusif, bertindak objektif, serta tidak diskriminatif karena pertimbangan jenis kelamin, agama, ras, kondisi fisik, latar belakang keluarga, dan status sosial ekonomi; b) Berkomunikasi secara efektif, empati, dan santun dengan sesama pendidik, tenaga kependidikan, orang tua, dan masyarakat; c) Beradaptasi di tempat bertugas di seluruh wilayah Republik Indonesia yang memiliki keragaman sosial budaya; dan d) Berkomunikasi dengan komunitas profesi sendiri dan profesi lain secara lisan dan tulisan atau bentuk lain.

Keempat, kompetensi profesional meliputi: a) Menguasai materi, struktur, konsep, dan pola pikir keilmuan yang mendukung mata pelajaran yang diampu; b) Menguasai standar kompetensi dan kompetensi dasar mata pelajaran/bidang pengembangan yang diampu; c) Mengembangkan materi pembelajaran yang diampu secara kreatif; d) Mengembangkan 
profesionalitas secara berkelanjutan dengan melakukan tindakan reflektif; e) Memanfaatkan teknologi informasi dan komunikasi untuk berkomunikasi dan mengembangkan diri.

\section{METODE PENELITIAN}

Penelitian ini berupaya untuk mengetahui proses pengelolaan dan pemberdayaan guru Non PNS di madrasah. Penelitian ini menggunakan pendekatan kualitatif, dengan kategori survei pada taraf deskriptif kualitatif. Penelitian dilaksanakan di Kota Kendari Provinsi Sulawesi Tenggara. Penentuan lokasi berdasarkan letak madrasah negeri berada di dalam kota dan sesuai ketentuan penganggaran dari RK-AKL Balai Litbang Agama Makassar.

Teknik pengumpulan datanya dengan menggunakan angket sebagai instrumen penelitian kemudian diikuti wawancara mendalam, observasi, dan studi dokumentasi. Perilaku, persepsi, tindakan, dan lain-lain secara holistik di deskripsikan secara kata-kata dan bahasa, dengan memanfaatkan berbagai metode alamiah. (J. Moleong, 2008:6).

Sumber dan jenis datanya berupa data primer dan data sekunder. Data primer yang dibutuhkan penelitian ini akan diperoleh dari sumber primer, yaitu kepala madrasah, guru Non PNS, serta guru lainnya. Sementara data sekunder akan ditemukan dari sumber data sekunder yaitu data administrasi madrasah, aturan dan program penataan pembelajaran yang dirancang oleh madrasah, dan data pendukung lainnya yang diperoleh dari instansi penyedia data pendidikan. Data yang diperoleh dari kegiatan penelitian akan dianalisis dengan tahapan: identifikasi data, reduksi data, klasifikasi data, sintesis data, interpretasi data, kemudian konklusi.

Adapun bentuk daftar pertanyaan di dalam angket yang diedarkan, adalah sebagai berikut:

\begin{tabular}{|c|c|c|c|}
\hline Deskripsi Fokus & Dimensi & Sub dimensi & Informan \\
\hline \multirow{10}{*}{ Strategi Rekrutmen } & \multirow[t]{2}{*}{ Perencanaan } & Analisis kebutuhan & \multirow{11}{*}{$\begin{array}{l}\text { Kepala } \\
\text { sekolah, } \\
\text { Panitia } \\
\text { seleksi, } \\
\text { guru, } \\
\text { Pihak } \\
\text { Kemenag } \\
\text { dan } \\
\text { Pihak } \\
\text { Kanwil. }\end{array}$} \\
\hline & & Penjadwalan & \\
\hline & \multirow[t]{2}{*}{ Pengorganisasian } & Panitia rekrutmen & \\
\hline & & Tim seleksi & \\
\hline & \multirow[t]{2}{*}{ Pelaksanaan } & Pengumuman & \\
\hline & & Persyaratan administrasi & \\
\hline & Pengawasan & $\begin{array}{l}\text { Hambatan, kerugian, penyalah } \\
\text { gunaan kewenangan, } \\
\text { penyimpangan, } \\
\text { pemborosan anggaran }\end{array}$ & \\
\hline & Penugasan & Perencanaan & \\
\hline & & Pengawasan & \\
\hline & & & \\
\hline $\begin{array}{l}\text { Pemberdayaan guru } \\
\text { non PNS }\end{array}$ & $\begin{array}{l}\text { Penciptaan } \\
\text { berkembang }\end{array}$ & $\begin{array}{l}\text { Kebijakan memberikan } \\
\text { peluang kepada guru non PNS } \\
\text { untuk bebas bertindak, terlibat } \\
\text { dalam proses pendidikan, } \\
\text { standar dan pengakuan telah } \\
\text { menjalankan tugas dengan baik }\end{array}$ & \\
\hline
\end{tabular}


Educandum: Volume 6 Nomor 1 Juni 2020

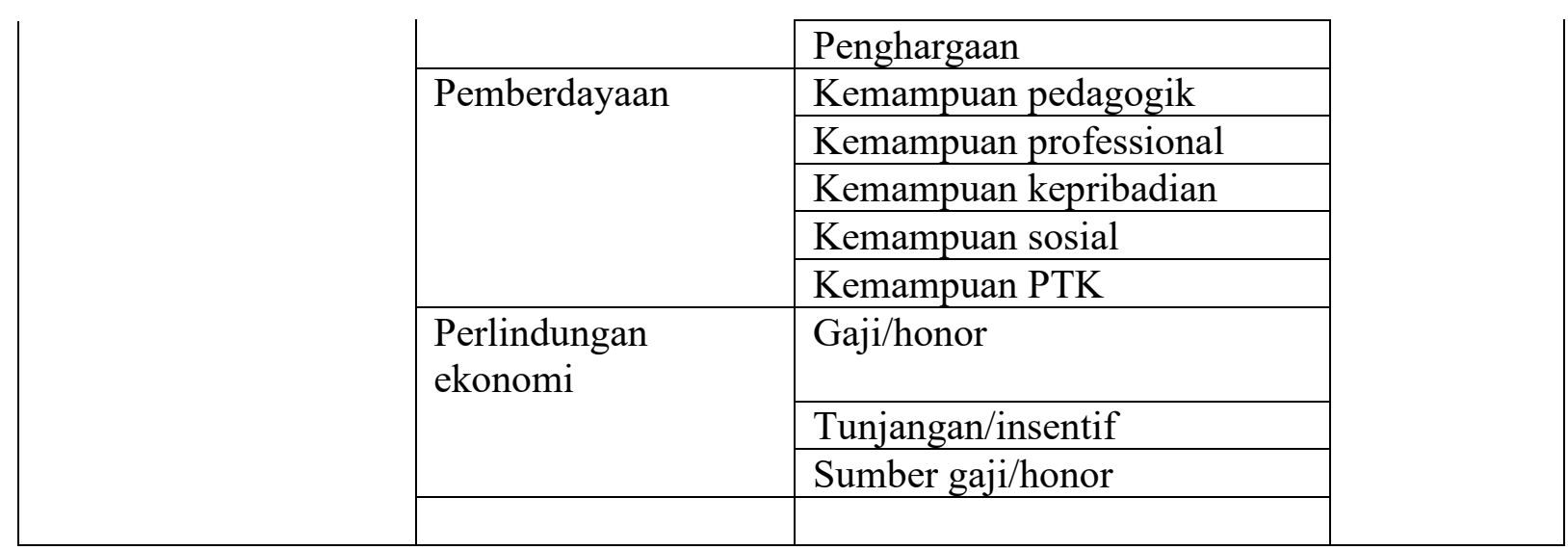

\section{PEMBAHASAN}

\section{Sekilas Lokasi Penelitian}

Untuk kesekian kalinya peneliti menginjak kaki di bumi Anoa Kota Kendari. Memang diakui bahwa Kota Kendari mempunyai daya tarik tersendiri. Terutama bagi mereka yang suka berpelisiran ke berbagai kota di Indonesia. Kini Kota Kendari terus berbenah mempercantik diri untuk menggaet wisatawan. Terkenal sekarang yaitu tempat wisata teluk Kendari dan kulinernya. Tapi bagi peneliti sendiri, yang menarik adalah tempat penjualan barang-barang bekas dar iluar negeri yang lebih familiar di Kendari yaitu RB (barang-barang bekas). Barangbarang RB ini meskipun bekas, tapi murah. Menariknya karena banyak yang bermerk internasional.

Ada pemandangan mata yang berbeda seperti biasanya, ketika tiba di bandaran Haluoleo Kendari, tampaknya orang-orang Tiongkok bertambah ramai di sana, ini tentu beralasan karena di Provinsi Sulawesi Tenggara termasuk salah satu provinsi basis orang-orang Tiongkok sebagai pekerja tambang dan semacamnya. Selain itu, banyak pengusaha dari Tiongkok yang menanamkan sahamnya di Provinsi Sulawesi Tengara ini.

Pada saat penelitian dilakukan pada bulan Juni 2019, masyarakat Kendari dalam keadaan berduka, di mana beberapa kabupaten telah dilanda banjir bandang, terparah di Kabupaten Konawe Utara. Masyarakatnya bahu membahu mengumpulkan sembako, barang-barang bekas yang layak dipakai untuk disumbangkan demi meringankan beban mereka.

Berdasarkan posisi geografis Kota Kendari memiliki batas-batas, sebagai berikut: Sebelah Utara Kabupaten Konawe; Sebelah Timur Laut Kendari; Sebelah Selatan dan Barat Kabupaten Konawe Selatan.

Heterogenitas masyarakat Kota Kendari dapat diamati dan disaksikan, mereka hidup rukun berdampingan dengan damai menjaga persatuan dan kesatuan. Stabilitas daerah tetap terjaga dengan baik. Perkembangan pembangunan dari waktu ke waktu terus berjalan sebagai pertanda kemajuan suatu daerah.

\section{Penduduk}

Hampir semua etnis ada di Kota Kendari. Suku besar seperti Tolaki, Muna, Buton, Bugis-Makassar. Suku-suku tersebut banyak mendiami Kota Kendari. Adapun jumlah penduduk Kota Kendari menurut data BPS Kota Kendari Tahun 2017 adalah: Laki-laki 187.233 jiwa $(50,50 \%)$ dan perempuan 183.495 jiwa $(49,50 \%)$, dengan rasio jenis kelamin 102,0.

Terdapat 11 kecamatan di Kota Kendari, yaitu: Kecamatan Kendari, Kendari Barat, Mandonga, Puuwatu, Kadia, Wua-Wua, Baruga, Poasia, Kambu, Abeli, dan Kecamatan Nambo. Dengan 65 kelurahan di Kota Kendari. Kecamatan yang paling padat penduduknya adalah Kecamatan Kadia, dan kecamatan yang paling sedikit penduduknya adalah Kecamatan Nambo. 
Kepadatan penduduk di KotaKendari tahun 2017 mencapai 1.259jiwa/km2. Kepadatan Penduduk di 11 kecamatan cukup beragam dengan kepadatan penduduk tertinggi terletakdi Kecamatan Kadia dengan kepadatansebesar 6.593 jiwa/km2 dan terendah diKecamatan Nambo sebesar 415jiwa/Km2. (BPS Kota Kendari, 2018).

\section{Agama}

Penganut agama Islam yang mayoritas di Kota Kendari, menyusul penganut agama Keristen, agama Katholik, dan agama Hindu.Menurut data dari Kantor Wilayah Kementerian Agama Provinsi Sulawesi Tenggara 2018, jumlah penduduk yang beragama Islam 289.401 jiwa; Kristen 11.300 jiwa; Katolik 7.146 jiwa; Hindu 2.434 jiwa; Budha 842 jiwa; Konghucu 106 jiwa.

\section{Lembaga Pendidikan Agama di Kota Kendari}

Kondisi lembaga madrasah di Kota Kendari mulai dari Raudhatul Athfal (RA) sampai Madrasah Aliyah (MA) diidentifikasi terdapat 26 RA, 16 Madrasah Ibtidaiyah (MI) satu MI Negeri, 15 Madrasah Tsanawiyah (MTs), 2 MTs Negeri, dan 7 MA, 2 Madrasah Aliyah Negeri. Dengan jumlah guru PNS sebanyak 956 orang guru dan Non PNS sebanyak 136 orang. Sementara guru Non PNS di madrasah sebanyak 78 orang. (Sumber: Kanwil Kemenag Provinsi Sultra, 2018).

Penelitian ini menyasar guru non PNS di madrasah negeri yang ada di dalam Kota Kendari. Adapun madrasah negeri di Kota Kendari sebagai objek penelitian, yaitu: MIN, MTsN 1, dan MAN 1,yang dianggap representatif dan dianggap banyak memiliki guru non PNS.

\section{Sekilas Sasaran Penelitian MIN Kota Kendari}

Madrasah Ibtidaiyah Negeri (MIN) Kendari yang beralamat di Jl. Pembangunan No. 16 Kelurahan Sanua Kecamatan Kendari Barat, awalnya adalah madrasah ibtidaiyah swasta DDI dulunya beralamat di Kelurahan Kadia. Selang beberapa waktu dengan adanya keinginan masyarakat dan perkembangannya, maka madrasah ini berubah status dari swasta menjadi negeri. Tepatnya pada tanggal 15 Februari 1968. Sejak berdirinya hingga sekarang telah mengalami pergantian kepala sekolah, antara lain: tahun 19681976 dipimpin oleh M. Syukur, 1976-1982 oleh M. Nawawi, 1982-1984 oleh M. Ashar Paccing, 1984-1988 oleh M. Marhabang, 1988-2005 oleh St. Nursiah Dessu, 20052007 oleh Rahim, 2007-2009 La Ode Fajar, 2009-2015 oleh Supriadi, dan 2015 sampai sekarang oleh Jumasni.

Adapun tenaga pendidik di MIN terdiri atas, 28 orang guru PNS, 5 di antaranya guru non PNS. Dengan jumlah rombongan kelas dan peserta didik sebagai berikut: Kelas I, 3 rombel, Kelas II, 3 rombel, Kelas III 4 rombel, Kelas IV, 3 rombel, Kelas V, 3 rombel, dan Kelas VI, 2 rombel.

\section{MTsN 1 Kota Kendari}

Madrasah Tsanawiyah Negeri 1 Kendari, beralamat di Jl. Antero Hamra No. 2 Kel. Bende KecamatanKadia Kota Kendari, merupakan madrasah negeri yang cukup diminati oleh masyarakat Kota Kendari.

Dibawah kepemimpinan La Duku, madrasah ini semakin maju dan berkembang, sehingga setiap pendaftaran peserta didik selalu kelebihan peserta didik.

Berdasarkan data Emis pada tahun 2013/2014 jumlahnya hanya 900 peserta didik dan meningkat menjadi 1.066 peserta didik pada tahun 2016/2017. Jumlah rombelnya Kelas VII, 11 rombel, Kelas VIII, 9 rombel, dan Kelas IX, 10 rombel. Adapun jumlah tenaga pendidik sebanyak 65 orang, terdiri atas 44 orang guru PNS dan 21 orang guru non PNS.

\section{MAN 1 Kota Kendari}

Madrasah Aliyah Negeri 1 (MAN 1) beralamat di J1. Pasaeno No.3 Kel. Bende Kecamatan Kadia Kota Kendari. Madrasah 
inisebelumnya adalah PGAN Kendari yang beralih fungsi pada tanggal 25 April 1990 melalui Surat Keputusan Menteri Agama RI Nomor:64/1990.Setelah berstatus Madrasah Aliyah Negeri 1 selama kurang lebih 15 tahun, MAN 1 Kendari diberi tanggung jawab menjadi salah satu Madrasah Aliyah Model yang berkedudukan di Sulawesi Tenggara dari 35 MA Model di Indonesia dengan keputusan Direktur Jenderal Pembinaan Kelembagaan Agama Islam Kementerian Agama RI, Nomor E.IV/PP.00.6/KEP/17.A/98, tanggal 20 Februari 1998 tentang Madrasah Aliyah Model. Berdasarkan surat keputusan tersebut MAN 1 Kendari diharapkan dapat berfungsi sebagai percontohan, pusat sumber belajar dan pemberdayaan madrasah yang ada di sekitarnya.

Sejak PGAN Kendari beralih fungsi menjadi Madrasah Aliyah Negeri (MAN 1) Kendari telah beberapa kali berganti Kepada Madrasah, yaitu: Drs.H. S. Muh.Al Jufri, masa jabatan 25 April 1990 s.d 10 Oktober 1994. Drs. H. Alimuddin K, masa jabatan 10 Oktober 1994 s.d 24 Januari 2000; Drs.H. M. Dahlan P, masa jabatan 24 Januari 2000 s.d11 Desember 2002; Drs. H. Alimuddin K, masa jabatan 11 Desember 2002 sampai 2007; Drs. Syahbuddin, masa jabatan 2007-2009; Ma'sud Achmad, S.Pd., M.Pd 2009-2012; Dra.Hj. Syamsyiar, S.Pd. M.Hum. Februari 2012-Februari 2015; Ma'sud Achmad, S.Pd., M.Pd. Februari 2015-2019. (Profil MAN 1 Kendari, 2018).

Adapun jumlah tenaga pendidik sebanyak 75 orang, terdiri atas 44 orang guru PNS dan 31 orang guru non PNS. Dengan jumlah rombel: Kelas X, 9 rombel, Kelas XI, 9 rombel, dan Kelas XII, 5 rombel.

\section{PENGELOLAAN GURU NON PNS Rekrutmen}

Analisis kebutuhan guru menjadi parameter utama dalam menentukan angkakebutuhan guru, proses analisis tersebut tidak bisa dilakukan atas dasar pertimbangan intuitifatau kira-kira, namun harus dihitung berdasarkan data kenyataan.
Setelah melewati prosesanalisis kebutuhan baru dilakukan analisis pemetaan kebutuhan guru di lapangan. Dalam satukecamatan atau kabupaten pasti terdapat sekolah yang kelebihan tenaga guru. Tahapan ini sangat penting dalam upaya untukpemerataan persebaran guru. (Asep Sunandar: Sistem rekrutmen dan manajerial komptensi guru honorer. http://ap.fip.um.ac.id/wpcontent/uploads/2 015/10/4-Asep-Sunandar.pdf.12/`09/2019).

Rekrutmen dilakukan atas dasar kebutuhan departemen yang telah disetujui oleh pimpinan puncak (board of director), dan kebutuhan tersebut mengacu pada standar yang sudah ditetapkan berdasarkan analisa jabatan (job analisys) yang dituangkan dalam uraian pekerjaan (job description). (Edison 2010:58)

Mekanisme perekrutan guru di madrasah sasaran penelitian (MIN, MTsN 1, dan MAN 1 Kendari) terkesan belum maksimal. Meskipun setiap tahun gurunya di data ketersediaan gurunya. Apakah ada kekurangan atau kelebihan guru. Kalaupun ada kekurangan guru, maka madrasah mengusulkan untuk melakukan rekrutmen guru. Namun, faktanya guru PNS yang lolos rekruitmen terkadang tidak mengajar di madrasah tempat mereka mengabdi atau guru yang diterima tidak sesuai dengan kebutuhan guru mata pelajaran yang diusulkan. Terkadang juga penempatan guru di madrasah tidak sesuai dengan kebutuhan madrasah. Ini artinya mekanisme rekrutmen di madrasah belum berjalan sebagaimana mestinya.

Dalam proses rekruitmen tenaga SDM termasuk guru non PNS, paling tidak ada acuan standar yang dipedomani. Dengan merujuk pada proses rekruitmen secara nasional, antara lain: mempublikasikan rekrutmen di media, penerimaan berkas lamaran, seleksi berkas, pengumuman kelulusan, tes, pemanggilan bagi yang lulus, psikotes/tes kesehatan, registrasi, dan penempatan.

Proses rekrutmen guru non PNS di madrasah sasaran penelitian, dominan dilakukan secara mandiri. Artinya semua 
pelaksanaannya mulai dari pengumuman sampai penentuan kelulusan dipegang langsung oleh madrasah yang bersangkutan. Tidak ada pembentukan tim seleksi secara khusus, kemudian tidak ada publikasi, pengumuman, dan sebagainya.

Rekrutmen guru non PNS biasanya dilakukan karena ketersediaan guru di madrasah tidak sebanding dengan jumlah peserta didik (rombel) yang dihadapi. Di samping itu, guru yang mengajar mata pelajaran tertentu sudah pindah tugas atau telah purnabakti.

Adapun proses rekrutmen guru non PNS pada madrasah yang diteliti (MIN,
MTsN 1, dan MAN 1 Kendari) alurnya sebagai berikut:: (1) Kepala madrasah mengadakan rapat dengan dewan guru untuk membicarakan rekrutmen guru non PNS; (2) Dari hasil rapat tersebut, informasi kebutuhan guru menyebar ketempat lain, seperti rekan guru, teman sejawat, grup WA, dan sebagainya; (3) Calon guru datang ke madrasah berdasarkan informasi yang diterima; Kepala sekolah menyeleksi; (4) Tes dan Wawancara;

Pemanggilan/Penugasan. Jika digambarkan dengan bagan sebagai berikut:

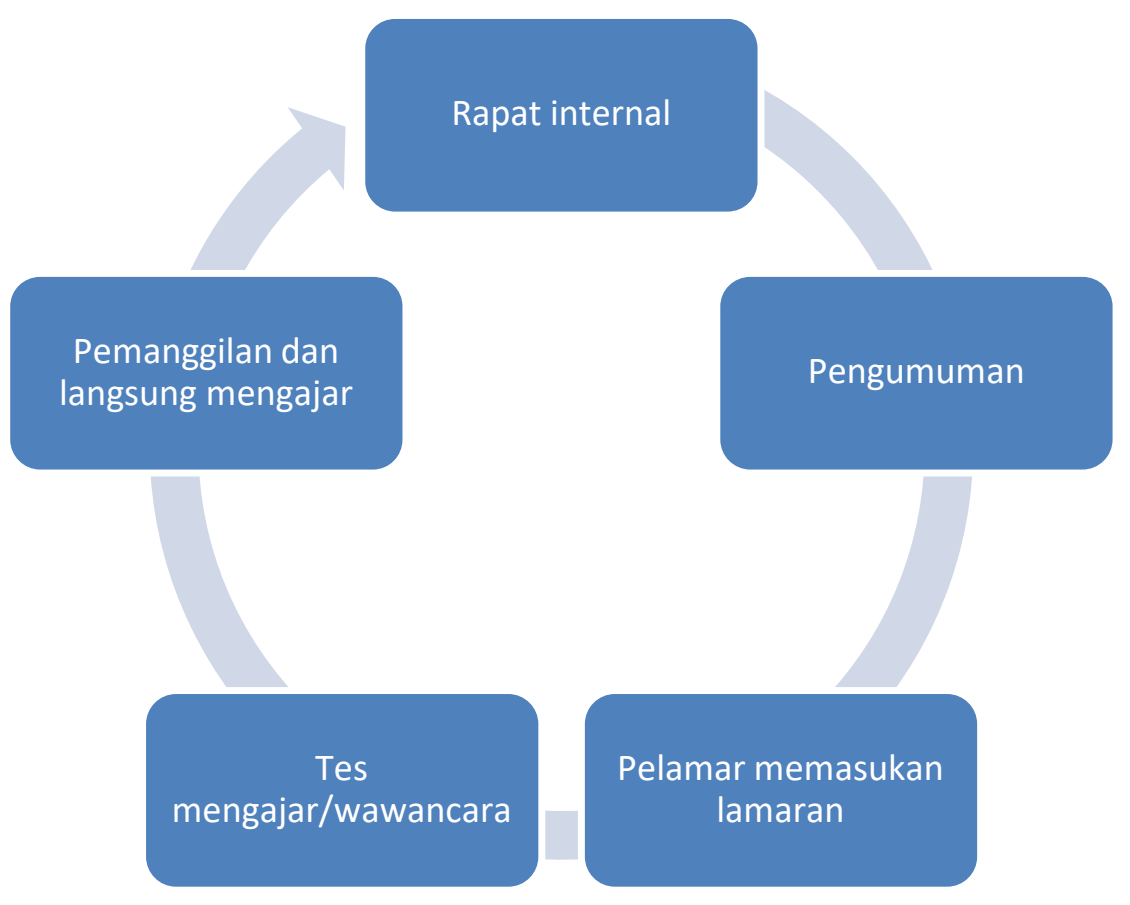

Dengan alur mekanisme yang tidak terlalu berbelit-belit tersebut, pihak madrasah beralasan, bahwa dengan diberikannya amanat kepada kepala madrasah untuk menjalankan visi misi madrasah, tentunya yang lebih mengerti persoalan madrasah termasuk kebutuhan SDM atau guru adalah kepala madrasah. Maka perekrutan secara mandiri dilakukan, antara lain untuk mendapatkan calon guru secara cepat. Di samping itu, kondisi psikologi dan kompetensi calon guru yang mengajukan lamaran sudah diidentifikasi, apalagi jika itu alumni madrasah. Dengan mendelegasikan ke pihak lain, tentunya membutuhkan proses yang berbelit-belit dan membutuhkan dana. Seperti yang dituturkan oleh Kepala Madrasah MAN 1 Kendari Pak Ma'sud Achmad, bahwa:

"Persoalan rekruitmen guru non PNS biasanya kami dianggap melanggar prosedur yang ada, kalau kami kekurangan guru bidang studi tertentu, kami langsung mengangkat guru non PNS, menurut perspektif kami, tentu yang memenuhi kebutuhannya sekolah sesuai dengan kebutuhan visi misi madrasah, karena kami yang tahu kondisinya, butuh guru dengan kualifikasi tertentu 
misalnya mengerti IT. Kemampuan apa saja yang mendapat nilai " $A$ " misalnya bahasa Inggris, IT, kondisi psikologinya dan sebagainya, dan belum berkeluarga, supaya all out di sekolah. Kami tidak melibatkan pihak lain dan mengumumkan, biasanya kami umumkan lewat WA group alumni, karena rata-rata mereka dari alumni yang mempunyai prestasi akademik di atas rata-rata." (Wawancara, tanggal 23/07/2019).

Hal senada juga diungkapkan oleh Kepala MIN Kendari ibu Sitt I Juhasni, bahwa:

"Rekrutmen guru non PNS kami lakukan sendiri, yang dibutuhkan ijazahnya kemudian wawancara, bahkan saya pernah langsung mengangkat/memanggil guru honorer untuk mengajar di sekolah kami. Saya anggap dia lebih memahami dan berkompeten, karena saya sudah tahukondisinya." (Wawancara, tanggal 18/07/2019).

Hal ini pula yang dilakukan oleh KepalaMTsN 1 Kendari dengan mengangkat secara langsung guru non PNS, berikut penuturannya:

"Sebenarnya umumnya di madrasah yang ada di Kendari ini kita masih kekurangan guru. Keberadaan guru non PNS di madrasah memang sangat diperlukan untuk melengkapi guru PNS yang terbatas itu. Terutam adi MTsN 1, pada mata pelajaran yang belum mempunyai guru PNS seperti mata pelajaran Seni Budaya, Prakarya, dan guru BK. Begitupun dengan kelas dan mata pelajaran yang mempunya irombel yang cukup banyak sekarang ini. Tahun ini saja, kami kewalahan menerima calon peserta didik. Ruang kelas kami juga terbatas." (Wawancara, 19/06/2019).

Dari berbagai argumen di atas terkait rekruitmen calon guru non PNS pada madrasah reguler, secara garis besarnya peneliti menyimpulkan, bahwa mekanisme rekruitmen telah dilakukan secara mandiri oleh madrasah yang bersangkutan, dengan standar dan kriteria yang ditetapkan oleh kepala madrasah. Meskipun proses dan mekanismenya sangat terbatas, belum melalui mekanisme yang baku, layaknya proses rekrutmen PNS secara nasional.

\section{Penugasan}

Kepala madrasah adalah orang yang memahami kinerja para bawahannya, termasuk memahami kemampuan guru terkait perencanaan pembelajaran, pelaksanaan pembelajaran, kemampuan membina hubungan, kemampuan melaksanakan pengayaan, kemampuan melaksanakan remedial, kemampuan melaksanakan penilaian, serta programprogram tindak lanjutnya.

Berdasarkan dengan tingkat kemampuan masing-masing guru, demi untuk menjamin kelancaran pelaksanaan proses pembelajaran, maka pembagian tugas mengajar perlu dibuat oleh kepala madrasah. Pembagian tugas dan tanggungjawab ini telah menjadi kesepakatan bersama untuk menjadi rujukan dalam pelaksanaan program.

Hasil rapat dewan guru setiap awal semester itu, setiap kepala madrasah di Kota Kendari membuat surat keputusan tentang uraian tugas pembagian mengajar setiap awal semester. Setiap guru baik PNS maupun non PNS, wajib melaksanakan tugasnya berdasarkan surat keputusan tersebut. Seperti pada kasus di MTsN 1 Kendari. Setelah gurunya dinyatakan lulus, maka ditugaskan langsung mengajar di kelas. Nanti pada semester kedua, mereka dibuatkan SK penugasan oleh kepala madrasah. Setiap akhir tahun kepala madrasah atau Kemenag Kota Kendari mengeluarkan SK baik untuk penungasan guru non PNS maupun pegawai honorer lainnya.

Berikut penuturan salah seorang guru non PNS MTsN 1 Kendari Pak Ahmad Amiruddin, bahwa:

"Ketika lulus dan diangkat jadi guru pada semester satu dan ditugaskan mengajar, nanti pada semester dua baru dibuatkan SK nya. Pembagian 
jam mengajar guru bervariasi, ada yang mengambil 24 jam, 28 jam, bahkan ada yang sampai 30 jam." (Wawancara, 20/07/2019).

Hal serupa juga terjadi di MIN Kendari. Guru non PNS yang diterima dibuatkan SK penugasan dan langsung mengajar di kelas, meskipun mereka mengajar tidak full di madrasah, hanya 2 kali seminggu, sehingga ada beberapa orang guru non PNS mengajar sambilan di sekolah lain. Di samping itu, penanganan kelas relatif lebih mudah di atasi, karena satu guru bisa menangani satu kelas dan bisa juga memegang semua mata pelajaran.

SK tersebut memuat antara lain nama guru yang ditugaskan, mata pelajaran, alokasi waktu, dan tugas tambahan. Seperti yang dilontarkan oleh Kepala Sekolah MIN Kota Kendari ibu Sumarni, bahwa:

"Setiap awal semester, kepala madrasah membuat surat keputusan pembagian tugas mengajar. Di dalam keputusan tersebut dicantumkan nama guru, mata pelajaran, alokasi waktu, dan tugas tambahan. Setiap guru melaksanakan tugasnya yang dipandang mampu dan cakap oleh kepala madrasah." (Wawancara, 22/07/2019).

Demikian pula penugasan seorang guru non PNS di MAN 1 Kendari. Guru PNS dan non PNS diserahi tugas berdasarkan rapat dewan guru setiap awal semester. Kepala madrasah membuat surat keputusan tentang uraian tugas pembagian mengajar setiap awal semester. Setiap guru baik PNS maupun non PNS, wajib melaksanakan tugasnya berdasarkan surat keputusan tersebut. Beban mengajar guru non PNS di MAN 1 Kendari, antara 12 jam s.d. 39 jam mengajar.

Masing-masing guru, bertanggungjawab atas tugas yang dibebankan. Untuk melihat kinerja mereka kepala madrasah melakukan pengawasan atau supervisi. Apakah pengawasan terhadap hambatan, kerugian, penyalahgunaan kewenangan, penyimpangan, atau pemborosan pada penugasan guru non PNS.

\section{PEMBERDAYAAN GURU NON PNS Penciptaan Iklim Sekolah}

Motivasi seseorang dalam sebuah pekerjaan sangatlah diperlukan. Dalam hal ini guru yang merupakan tenaga pendidik seharusnya memiliki motivasi yang tinggi dalam bekerja. Motivasi kerja adalah sesuatu yang menimbulkan dorongan atau semangat kerja atau dengan kata lain pendorong semangat kerja. (Haribowo, 2015:24)

Motivasi kerja yang diungkapkan oleh Pinder (1998, dalam Baleghizadeh, 2012) bahwa motivasi kerja adalah seperangkat kekuatan energik yang berasal baik dari dalam maupun luar individu, untuk memulai perilaku yang berhubungan dengan pekerjaan, serta menentukan pada bentuk, arah, intensitas, dan durasi. Kekuatan energik ini berguna untuk memulai pekerjaan dengan semangat dan pada akhirnya memaksimalkan kinerja yang dilakukan. Di samping itu, iklim sekolah yang kondusif juga merupakan faktor penting di dalam menentukan semangat dalam melaksanakan tugas dan tanggungjawab seorang guru. (Balaghizadeh, 2012:30).

Di dalam PP Nomor 19 Tahun 2017 tentang Perubahan Atas PP Nomor 74 Tahun 2008 pada pasal 1 ayat (10), bahwa guru dalam jabatan adalah guru pegawai negeri sipil dan guru bukan pegawai negeri sipil yang sudah mengajar pada satuan pendidikan, baik yang diselenggarakan oleh pemerintah pusat, pemerintah daerah, maupun masyarakat penyelenggara pendidikan yang sudah mempunyai perjanjian kerja atau kesepakatan kerja bersama.

Guru PNS dan non PNS memiliki tugas dan tanggungjawab yang sama di madrasah dalam rangka mencerdaskan peserta didik. Perlakuan guru non PNS terkait pemberdayaannya juga demikian. Guru non PNS diberikan peluang dan kebebasan untuk menyesuaikan diri dengan tugas yang diemban. Bahkan mereka lebih kreatif dan selalu berinovasi dibandingkan 
dengan sebagian guru PNS dalam hal pembelajaran di kelas. Hanya saja, pemberdayaan berupa pendidikan dan latihan memang masih sangat minim.

Keluwesan bertindak dalam menunaikan tugas yang diemban sama dengan guru PNS dalam proses pembelajaran. Seperti yang terjadi di MAN 1 Kendari.

Kepala madrasah sangat mengapresiasi guru non PNS yang telah melaksanakan tugas dengan baik. Apresiasi tersebut diwujudkan dengan pemberian tugas tambahan seperti wali kelas, membina kegiatan ekskul, dan berbagai kegiatan kepanitiaan. Hampir semua kegiatan ekskul di madrasah sasaran penelitian dibina oleh guru non PNS. Seperti seperti membina olimpiade KSM itu, karena mereka-mereka ini dianggap fokus dan sungguh-sungguh. (Wawancara, 23/07/2019).

Tidak di pungkiri dalam satuan Pendidikan mana pun dipastikan akan ada bagian-bagian tertentu yang tampak di permukaan dan yang tersembunyi. Bagian yang tampak bisa dilihat secara langsung seperti visi misi sekolah, sumber keuangan, fasilitas, SDM tenaga pendidik dan kependidikan. Sementara yang tersembunyi seperti iklim kerja, norma-norma, sikap, dan perasaan setiap individu warga sekolah. Terkadang memang dijumpai berbagai keluhan atau merasa iri dengan rekannya guru yang PNS. Secara spontan muncul pada diri guru non PNS. Lagi-lagi masalah kinerja guru PNS yang banyak disoroti oleh guru non PNS. Seperti yang dikemukakan salah seorang guru non PNS berinisial DS, bahwa:

"Gaji mereka sudah tinggi tapi tidak paraler dengan kinerja mereka mengajar. Sementara kita yang guru non PNS terkadang ada guru PNS mendelegasikan beban kerja mengajarnya kepada kita, padahal mereka sudah digaji cukup tinggi". (Wawancara, 20/07/2019).

Kepala madrasah sebagai pemegang otoritas di madrasah, masih menomor satukan guru yang sudah PNS untuk mengikuti diklat, terutama diklat di luar daerah. Apalagi pemanggilan peserta diklat terbatas. Keikutsertaan guru non PNS dalam diklat hanya sebatas "pemain cadangan" jika guru PNS yang di undang berhalangan hadir.

\section{Peningkatan Kompetensi}

Guru sangatlah berperan dalam mencerdaskan kehidupan bangsa, sehingga seorang guru haruslah berkualitas dalam mentransfer ilmu yang dia miliki kepada peserta didiknya. Guru adalah SDM yang sangat penting dalam kehidupan manusia, maka dari itu kinerja seorang guru akan sangat menentukan masa depan suatu bangsa (Haribowo, 2015:23). Kualitas pendidikan guru melalui peningkatan kompetensi guru untuk mengembangkan proses pembelajaran yang menyenangkan, kreatif dan inovatif bagi peserta didik adalah keniscayaan.

Telah dijelaskan dalam Peraturan Menteri Pendidikan Nasional RI Nomor 16 Tahun 2007 Tentang Standar kualitas akademik dan kompetensi guru, mencakup: kompetensi pedagogik; kompetensi kepribadian; kompetensi sosial; dan kompetensi profesional.

Pelibatan guru non PNS untuk meningkatkan kompetensinya dilakukan dengan berbagai kegiatan pemberdayaan yang dilaksanakan di madrasah, baik di intern madrasah, dari pihak Kemenag Provinsi/kabupaten, Diklat Kemenag, Dikbud, Pemda, maupun organisasi kemasyarakatan, seperti pendidikan dan latihan media pembelajaran, bimtek kepala laboratorium sekolah, kegiatan pengembangan kompetensi, KKG, MGMP, penelitian tindakan kelas, workshop seperti workshop penilaian pembelajaran, dan pembinaan secara intern dari madrasah.

Peningkatan kompetensi guru non PNS di MAN reguler berbeda di MAN Insan Cendekia (MAN IC). MAN IC adalah madrasah yang diunggulkan di jajaran Kementerian Agama. Sehingga mulai dari perekrutannya saja dilaksanakan secara nasional, guru yang lulus adalah guru-guru 
yang berkompeten di bidangnya. Kegiatan peningkatan kompetensi nya menjadi perhatian. Guru non PNS terus meningkatkan profesionalisme dalam rangka peningkatan kegiatan pembelajaran di kelas demi tercapainya prestasi belajar peserta didik.

Berbeda dengan madrasah reguler seperti di MIN, MTsN 1, dan MAN 1 Kendari, partisipasi guru non PNS dalam peningkatan kompetensi masih minim. Kalaupun ada permintaan diklat dari luar, kepala madrasah lebih mengutamakan guru PNS.

Minimnya kegiatan pengembangan kompetensi dapat dirasakan oleh guru non PNS di madrasah Kota Kendari. Tidak hanya dipengaruhi karena kurangnya anggaran madrasah tetapi juga kegiatankegiatan pengembangan kompetensi lebih diutamakan bagi guru PNS. Satu-satunya dana yang diharapkan adalah dana BOS. Itupun terbatas, sehingga kegiatan-kegiatan pendidikan dan latihan juga terbatas dilaksanakan. Terkadang sekali setahun atau setiap semester. Seperti yang dituturkan oleh salah seorang guru non PNS ibu Sumarni, bahwa:

"Biasanya hanya ikut kegiatan workshop dan kegiatan MGMP di sekolah tentang materi pembelajaran yang diadakan di sekolah setiap sekali satu tahun. Terkadang juga guru non PNS yang tergabung dalam MGMP, melaksanakan kegiatan MGMP saja kita dengan swadaya, supaya tetap jalan, meskipun tanpa biaya dari madrasah. Biasanya kami yang tergabung menyiapkan minum dan snacknya". 22/07/2019).

(Wawancara,

Menurut Sri Wahyuni salah seorang guru non PNS MIN Kendari, bahwa:

"Kegiatan untuk meningkatkan kompetensi guru non PNS di MIN Kendari, hanya berupa pembimbingan dari Kemenag Provinsi/kabupaten, dari pengawas, dan kegiatan KKG. Misalnya kegiatan KKG, dilakukan 2 kali setahun, kegiatan bimbingan dari Kemenag dan pengawas setiap semester. Kegiatan diklat hanya diperuntukkan bagi guru yang PNS saja." (Wawancara, 17/09/2019).

Demikian pula halnyadi MTsN 1 Kendari, intensitas kegiatan pengembangan kompetensi guru non PNS masihkurang, mereka hanya mengikuti kegiatan workshop yang dilaksanakan oleh madrasah setiap sekali dalam setahun. keterlibatan guru non PNS pada kegiatan MGMP juga masih terbatas.

\section{Jaminan Ekonomi}

Kejelasan status dan jaminan ekonomi sangat berpengaruh terhadap kinerja seorang guru mengingat kompensasi juga merupakan salah satu komponen yang sangat penting bagi setiap tenaga kerja karena kompensasi/balas jasa akan dipergunakan oleh tenaga kerja untuk memenuhi kebutuhan hidupnya dan keluarganya. Peterson dan Plowman (dalam Hasibuan, 2005) mengatakan bahwa orang mau bekerja karena hal-hal berikut: (a) the desire to live, artinya manusia bekerja untuk dapat makan dan minum untuk dapat melanjutkan hidupnya, (b) the desire for posession, artinya keinginan untuk memiliki sesuatu, (c) the desire for power, artinya keinginan akan kekuasaan, (d) the desire for recognation, artinya keinginan akan pengakuan. Motivasi seseorang dalam sebuah pekerjaan sangatlah diperlukan. Dalam hal ini guru yang merupakan tenaga pendidik seharusnya memiliki motivasi yang tinggi dalam bekerja. Motivasi kerja adalah sesuatu yang menimbulkan dorongan atau semangat kerja atau dengan kata lain pendorong semangat kerja. (Hasibuan, 2005).

Peningkatan kesejahteraan guru non PNS perlu mendapatkan prioritas dalam anggaran madrasah, sehingga layanan yang diberikan guru juga sebanding dengan apa yang diterimanya. Persoalan gaji atau honor guru non PNS menjadi dilema di madrasah, di satu sisi pihak madrasah dituntut ingin maju, sementara dana yang diberikan 
terbatas di sisi lain. Satu-satunya yang diharapkan untuk pembiayaan honor guru non PNS adalah dana BOS. Sementara dana BOS juga terbatas. Dana BOS dihitung berdasarkan standarnya adalah jumlah siswa baru. Misalnya jika siswa seribu orang, maka dananya bisa sampai 2 milyar. Tetapi tidak semua madrasah menggunakan dana BOS berdasarkan standar jumlah siswa. Standar mutu juga diharapkan menjadi dasar, karena masih banyak pembiayaan operasional lain yang lebih penting.

Dalam Undang-Undang Ketenagaan kerjaan menginstruksikan bahwa setiap pekerja/buruh berhak memperoleh penghasilan yang memenuhi penghidupan yang layak bagi kemanusiaan. Pengupahan atau honor guru non PNS di madrasah, jika mengacu kepada standar kebijakan pengupahan yang dikeluarkan oleh Undang-Undang Ketenagakerjaan. Sesuai dengan UMP pada Provinsi Sulawesi Tenggara dengan kisaran Rp.2.100.000,(dua juta seratus ribu rupiah). Dengan anggaran yang terbatas pada madrasah, maka untuk mengakomodir UMP provinsi belum bisa diaplikasikan di madrasah.

Kebijakan penghonoran gaji guru non PNS yang hanya bersumber dari dana BOS. Hal ini telah diatur di dalam Keputusan Dirjen Pendidikan Islam Nomor 511 Tahun 2019. Besaran honornya tergantung besaran jumlah dana BOS madrasah. Besaran honor guru non PNS di madrasah bisa saja berbeda-beda tergantung dana DIPA yang disediakan madrasah. Di samping itu, juga berapa besar dana komite sekolah sangat tergantung akan kemampuan orang tua peserta didik. Setiap kebijakan kepala madrasah terkait penganggaran di madrasah dibicarakan atau didiskusikan terlebih dahulu untuk mencapai mufakat yang melibatkan komponen pendidikan di madrasah, meliputi dewan guru dan komite madrasah.

Dari pengamatan peneliti di lapangan, di MIN Kendari, guru non PNS diberikan honor sebesar Rp. 300.000,- per bulan. Honor tersebut diberikan tidak berdasarkan jam mengajar guru. Semua guru non PNS diratakan honornya. Mereka juga diberikan gaji tambahan, seperti honor ketika mengawas pada saat ujian semester, dan kegiatan-kegiatan lainya.

Sementara di MTsN 1 Kendari diberi honor sebesar Rp. 7.500,- per jam. Besaran honor atau insentif guru non PNS di MTsN 1 Kendari berbeda-beda, sesuai dengan jam mengajarnya dan absensi kehadiran di madrasah. Adapun untuk guru non PNS yang bertugas sebagai guru $\mathrm{BK}$ diberi honor antara 300.000,-s.d. 700.000,- per bulannya. Besaran honor tersebut juga diperhitungkan dari tingkat kehadiran guru di madrasah. Menurut KTU MTsN 1 Kendari, bahwa:

"Honor dan insentif mereka bisa saja berbeda-beda tergantung jam mengajarnya dan kehadirannya di madrasah. Di samping itu, juga berapa besar dana komite sekolah sangat tergantung akan kemampuan orang tua peserta didik. Setiap kebijakan kepala madrasah terkait penganggaran di madrasah dibicarakan atau didiskusikan terlebih dahulu untuk mencapai mufakat yang melibatkan komponen pendidikan di madrasah, meliputi dewan guru dan komite madrasah" (Wawancara dengan KTU, 24/07/2019.

Adapun honor tambahannya bersumber dari ketika mereka dilibatkan pada kegiatan-kigiatan ekskul di sekolah, pada saat mengawas pada saat ujian semester, dan ketika membantu guru BK. Seperti yang diungkapkan oleh salah seorang guru non PNS MTsN 1 Pak Ahmad Amiruddin, bahwa:

"Honor tambahan kami peroleh misalnya ketika ujian semester, pada saat simulasi biasanya kami terima antara Rp.50.000,-s.d. Rp. 75.000, per kegiatannya. Begitupun pada hari pelaksanaannya biasanya bertambah antara Rp. 100.000,-s.d. Rp. 150.000,-. Begitu juga pada saat UNBK biasanya kami terima sampai 
Rp. 200.000,-“ $\quad$ (Wawancara, 20/07/2019).

Guru non PNS di MAN 1 Kendari diberi honor sebesar Rp 10.000/jam, juga bersumber dari dana BOS dan uang komite. Meskipun ada honor tambahan atau insentif lainnya, termasuk guru non PNS yang sudah mempunyai Nomor Pendidik Kemenag (NPK) dan sudah terdapat dalam Sistem Informasi Manajemen Pendidikan dan Kependidikan Kementerian Agama (Simpatika), berhak mendapat insenstif Rp. 250.000,-s.d. Rp 300.000,-perbulan dari Kemenag Kota Kendari. Itupun baru berjalan setahun ini (2019).

Menurut Kepala MAN 1 Kendari, bahwa:

"Honor guru non PNS di madrasah kami, memang tidak seberapa hanya Rp.10.000,- per jam. Bagi guru non PNS yang sudah tersertifikasi mendapat honor sebesar Rp. 1.500.000,- per bulan. Adapun tambahan-tambahan, memang pada DIPA madrasah tidak disebutkan besaran honor mengajarnya. Standar dana BOS sebenarnya berdasarkan jumlah siswa, tapi kami tidak memakai itu kami berstandarnya berbasis mutu. " (Wawancara, 20/06/2019).

Setiap guru non PNS mendapat tugas tambahan baik yang dibiayai oleh DIPA madrasah maupun yang bersumber dari dana BOS dan dana komite sekolah. Tambahan honor yang bersumber dari DIPA madrasah berupa dari kegiatankegiatan ekstrakurikuler, seperti sebagai pembina KSM, pembina kegiatan lomba olimpiade, dan sebagainya. Honor tambahan seperti membimbing KSM Olimpiade, bimbingan ekstra per minggu dan ekstra di luar, nilainya berpluaktuasi angkanya. Meskipun begitu, nilai ini masih belum mencukupi kebutuhan sehari-hari setiap guru non PNS. Menurut salah seorang guru non PNS ibu Murlina, bahwa:

"Honor tambahan didapatkan pada saat pelibatan dalam kepanitiaan yang dilaksanakan di madrasah, seperti panitia ujian nasional, ujian sekolah, ujian semester dan kegiatan-kegiatan pembimbingan kegiatan ekskul dan kegiatan sekolah lainnya. Misal jika dilibatkan jadi panitia ujian semester biasanya kami dapat Rp.150.000,perminggu."

(Wawancara, 21/06/2019).

Jika melihat dari paparan beberapa guru non PNS di atas, bahwa memang besaran honor mereka tidak cukup untuk kebutuhan sehari-hari. Bahkan, ada di antara mereka, selain mengajar di madrasah, mereka mencari pekerjaan sambilan di luar, seperti mengajar di sekolah lain, menjaga warung, dan usahausaha lainnya. Hanya saja, tidak semua guru di madrasah bisa mencari pekerjaan sambilan di luar, karena mereka juga dituntut untuk tetap di sekolah.

Terkait dana BOS di madrasah sebenarnya hanya diperuntukkan dana operasional sekolah dan peserta didik. Namun, seiring berjalannya waktu, kebijakan tersebut kembali berubah, dengan mengizinkan alokasi dana BOS untuk guru honorer, sekaligus menghapus larangan penggunaan dana BOS untuk gaji honorer. Meskipun dibolehkan, tetap saja ada penurunan dari segi besaran yang sebelumnya dipatok 20 persen, kini hanya sekitar 15 persen saja. (Rais, 2019:93).

Selain honor yang bersumber dari DIPA. Guru non PNS juga mendapat tambahan dari dana komite sekolah. Meskipun nilainya masih sangat sedikit. Dana komite yang bersumber dari orang tua itu hanya diorientasikan pada kebutuhan yang sifatnya mensupport kegiatankegiatan ekskul madrasah.

\section{PENUTUP}

Pengelolaan guru non PNS di setiap madrasah di Kota Kendari mulai dari perencanaan sampai rekruitmen dilakukan secara mandiri oleh pihak madrasah. Mekanisme rekruitmen seperti itu dianggap kepala madrasah sebagai jalan termudah memperoleh guru non PNS yang dianggap berkompeten sesuai kebutuhan madrasah. 
Di sampingitu, dengan model ini, penggunaan anggaran bisa diminimalisir. Prosesnya pun hanya didahului dengan rapat internal dan proses seleksi. Sehingga peluang calon pelamar untuk berkompetisi menjadi guru di madrasah sangat terbatas.

Pada aspek pemberdayaan, tidak ada perbedaan, baik guru PNS maupun non PNS telah mendapat perlakuan yang sama. Partisipasi aktif dalam kegiatan pemberdayaan seperti workshop, Bimbingan Teknis (bimtek), KKG, MGMP dan kegiatan pembimbingan dari Kemenag. Namun terkadang guru non PNS merasa dianggap sebagai cadangan dalam kegiatan diklat-diklat tertentu, baik yang dilaksanakan oleh Kementerian Agama maupun Pemerintah Daerah setempat.

Jaminan ekonomi berupa honor atau insentif guru non PNS di madrasah hanya bersumber dari dana BOS dan komite sekolah. Nominalnya pun berbeda-beda di setiap madrasah. Di MIN 1 Kota Kendari sebesar Rp. 300.000,- per bulan, pada MTsN 1 Kota Kendari sebesar Rp. 7.500,per jam. MAN 1 Kota Kendari mengupah guru non PNS sebesar Rp. 10.000,- per jam. Kemudian ada tambahan honor atau insentif tertentu pada kegiatan-kegiatan ekstrakurikuler dan lainnya. Honor atau insentif tersebut, masih tergolong di bawah Upah Minimum Provinsi (UMP) Kota Kendari, sehingga jaminan ekonomi tersebut belum bisa mencukupi kebutuhan hidup mereka sehari-hari.

Kedepannya diharapkan transparansi dan penyeragaman proses rekruitmen calon guru non PNS di madrasah negeri perlu diterapkan, layaknya rekrutmen PNS secara nasional, untuk menjamin kualifikasi dan kompetensi guru non PNS.

Peningkatan kompetensi guru non PNS perlu diprogramkan oleh pihak madrasah, Kantor Wilayah Kementerian Agama Provinsi dan Kementerian Agama Kabupaten secara khusus, untuk mengikutkan guru non PNS pada kegiatankegiatan diklat peningkatan kompetensi guru.

\section{UCAPAN TERIMA KASIH}

Penulis mengucapkan terima kasih kepada bapak H. Saprillah, S.Ag. M.Si selaku Kepala Balai Penelitian dan Pengembangan Agama Makassar, yang telah mengamanahkan penulis untuk meneliti di Kota Kendari. Terima kasih juga penulis sampaikan kepada kepala madrasah, tenaga pendidik dan tenaga kependidikan di madrasah sasaran penelitian ini, baik PNS maupun non PNS, dengan senang hati menerima peneliti dan memberikan data dan informasi untuk kepentingan penelitian ini. Ucapan terima kasih kepada Bapak DR. Badruzzaman, M.Pd, selaku koordinator dalam penelitian ini, dan kepada Bapak Amiruddin, M.Pd. selaku koordinator Bidang Pendidikan Agama dan Keagamaan Balai Litbang Agama Makassar, yang telah bersusah payah merancang dari awal penelitian ini serta koordinasinya di lapangan, juga kepada tim redaksi Jurnal Educandum yang bersedia memuat artikel ini.

\section{DAFTAR PUSTAKA}

Arikunto, S. 1993. Manjemen Penelitian. Jakarta: PT. Raja Grafindo Persada.

Asep Sunandar: Sistem rekrutmen dan manajerial komptensi guru honorer. http://ap.fip.um.ac.id/wpcontent/uploads/2015/10/4-AsepSunandar.pdf. 12/`09/2019).

Badruzzaman. 2018. "Pengelolaan dan Pemberdayaan Guru Non PNS di madrasah". Desain Operasional Penelitian. Makassar: Balai Penelitian dan Pengembangan Agama.

BPS. 2018. Kota Kendari Dalam Angka.

Baleghizadeh, S., \& Gordani, Y. (2012). Motivation and Quality of Work Life Among Secondary School Efl Teachers. Australian Journal of Teacher Education, 37(7), 30-42.

Edison, Imron.2010. Human Resource Development: Pengembangan Sumber Daya Manusia. Bandung: Alfabeta. Cet II April. 
Fattah, N. 2004. Konsep Manajemen Berbasis Sekolah (MBS) dan Dewan Sekolah. Bandung: Pustaka Bani Quraisi.

Griffin, R. W. 1990. Management. Boston: Houghton Mifflin Company.

Hamdar Arraiyyah. https://blamakassar.co.id/2019/10/22/guruhonorer-di-madrasah-negeripeluang-tantangan-danrespons/Diakses, tanggal 23/10/2019)

Hasibuan, S. P. M. (2005). Organisasi dan Motivasi. Jakarta: PT. Bumi Aksara

Haribowo, Herwindo, dkk. 2015. Motivasi Kerja Guru Honorer Ditinjau Dari Quality of Work Life. Jurnal Penelitian dan Pengukuran Psikologi, Vol. 4, No. 1. Jakarta: Universitas Negeri Jakarta.

J. Moleong. 2008. Metode Penelitian Kualitatif. Bandung: Remaja

Kamus Besar Bahasa Indonesia (KBBI) online.

https://typoonline.com.>kbbi.Diakse s 13/09/2018).

Kastasasmita, G. 1996. Pemberdayaan Masyarakat: Konsep Pembangungan Berakar pada Masyarakat. Jakarta: BAPPENAS.

Manaf. 2016. Hubungan Pemberdayaan Guru Terhadap Profesionalisme Guru dan Mutu Pendidikan. TANZHIM. Jurnal Penelitian Manajemen Pendidikan Vol.1 No.2 Tahun 2016 ISSN:2548-3978.

Qalyubi, S. 2007. Dasar-Dasar Ilmu Perpustakaan dan Informasi. Yogyakarta: Jurusan Ilmu Perpustakaan dan Informasi Universitas Fakultas Adap UIN Sunan Kalijaga Yogyakarta.

Rais, Muhammad. 2019. Pengelolaan dana BOS dan KIP di Madrasah. Bantul: Lintas Nalar.

Sunarto NS. 2004. Manajemen Perpustakaan. Jakarta: Samitra Media Utama. 